\title{
Determinants of Saving Behavior among Staff in International Islamic University College Selangor
}

\author{
NurulWajhiAhmad $^{\text {a, } 1}$, MawarMurniYunus ${ }^{\text {a, }}$, Nuzul Akhtar Baharudin ${ }^{\text {a, } 3}$, \\ NorhanizahJohari $^{\mathrm{a}, 4}$, NorazlinaRipain ${ }^{\mathrm{a}, 5}$ \\ ${ }^{\mathrm{a}}$ Faculty of Management and Muamalah, \\ International Islamic University College Selangor (KUIS), 43000 Bangi, Malaysia \\ 11 nurulwajhi@kuis.edu.my, ${ }^{2}$ mawarmurni@kuis.edu.my, ${ }^{3}$ nuzulakhtar@kuis.edu.my, \\ ${ }^{4}$ norhanizah@kuis.edu.my, ${ }^{5}$ norazlina.ripain@kuis.edu.my
}

\begin{abstract}
This paper analyses the relationship of saving behavior to financial management practice, financial distress, and financial literacy. This paper utilized questionnaire- based surveys to obtain information about saving behavior. The sample comprised of 150 KUIS staffs in academic and administration department. The study provides an in-depth analysis of respondents' financial management practice, financial distress, and financial literacy was measured with a 5-point Likert scale. The findings show that all the financial management practice, financial distress, and financial literacy have positive association with the saving behavior. All these 3 independent variables significantly predicted saving behavior. Furthermore, financial management practiceis the major determinants of saving behavior due to the strongest relationship with saving behavior.The results also indicate that KUIS need for financial education programs for staff to be directed at facilitating changes in financial management practices, diminish financial distress and improving financial knowledge. We have recommended that workplace financial education programs could improve staffs' financial constraints by reducing financial distress.
\end{abstract}

Keywords: saving behavior; financial management practice; financial distress; financial literacy.

\section{Introduction}

Saving is an important behavior that can promote long run economic growth particularly at individual and household level. Indeed, adequate level of saving amount will gives more financial freedom and opportunities for investment as well as future financial planning. Saving should be considered in the context of financial planning and financial management practices.

From an investment perspective, saving takes place when individual is able to spend less than income and set aside some amount of money every month. Yet, saving decision depends on many significant factors such as habits, wealth, preferences of consumption and real interest rate. In fact, the current economic landscape with the implementation of Goods and Services Tax (GST) will also affect saving pattern. Furthermore, the reasons for saving differ among income levels, with families at lower income levels saving for more immediate expenditures such as rent and holiday gifts, compared with the longer timeframe of 
savings by higher income groups for future expenditures such as children's education and retirement (McKean et al., 2005).On the other hand, increase in income does not necessarily motivate people to save, because some of them are tend to spend more of their earnings. Hence, in order to encourage saving, government policies should be focusing in providing more incentives and opportunities to save by offering wide range of instruments (Khan \&Abdullah, 2010). He suggested that financial system distortions should be eliminated or more specifically, financial liberalization should take place in order to encourage savers by offering them greater returns.

The government incentives such as offering higher return and effective monitoring policy will eventually enhance the overall economic growth. Supported by Abdullah, the increase in rate of return would encourage people to save more since there is higher return on their savings that attractpeople to save. Results shown that, $1 \%$ increase in rate of return would increase savings rate to about $2.87 \%$ in long run and about $0.62 \%$ in short run. However, this variable is only significant in long run with $1 \%$ significance level (Khan \&Abdullah, 2010). There are different views between savings and national growth. At country level, high saving and investment rates appear very desirable for improving national welfare (Rajni, 2010).

In recent years, the issue of individual bankruptcy in Malaysia has received more attention. According to Malaysia Department of Insolvency (MdI), from 2007 until September 2013, 116,488 people were declared bankrupt. In fact the number kept increasing each year. This statistic also represents the Malaysian youth financial situation. As reported by Ali (2013), those aged between 30-39 years old are more likely to experience financial distress compared to those 50 years and above-consistent with current observation that those declared bankrupt are getting younger.

Today, workers' debt is increasing faster than inflation. With the declining of employment opportunities, income instability and eroded purchasing power of Malaysian households, workers have to decide not only how much to save for retirement but also how to allocate their pension wealth (Delafrooz\&Paim, 2011a).Many significant factors contribute to the annual statistic and discourage people for not to save consistently. Overuse of credit, overspending, lack of budgeting, too many debts, inadequate shopping and spending skills, low salary and lack of knowledge about money are the main causes of employee financial problems (Delafrooz\&Paim, 2011b). Based on the study, low income and seasonal income earners are more vulnerable to financial distress.More surprisingly, higher educated individuals, higher financial knowledge does not necessarily translate into better financial management unless the values of living within our means is cultivated along financial knowledge (Ali, 2013).

All of the above discussion and statistics reveal a negative indicator on the financial conditions of Malaysians people. Perhaps, this situation may affect the long term quality of life. Thus, the main focuses of this survey are to examine the determinants of saving among KUIS staff and its relationship with their financial management, financial literacy and financial distress.

The objective of this study is twofold. First, it examines the major determinants of saving behavior among KUIS staff, and second, to describe the relationship between financial management, financial literacy, financial distress, and saving behavior. 


\section{Literature Review}

\section{i. Financial Management}

Finance is very critical resource to individual and every organization. Hence its proper management has engrossed much attention in the many literatures. In firms, fund is needed to acquire assets, long term investment and financing purposes to meet the objective of maximizing shareholder wealth. As for individual, people need money to allocate their day to day householdobligations. Evidence available demonstrates that financial management behaviors of households do not only foster the cohesion and mutuality within the household but also influence their savings and investment behaviors (Krah et al., 2014). Furthermore, Krah et al.(2014) and Hilgertet al. (2002) use 4 financial practices within thehousehold to explore the pattern of financial management practices and these include cash-flow management, credit management, saving, and investments.Financial management also is an essential practice that assists people in order to save for a better tomorrow and serve as emergency fund during rainy days. But before we start managing our financial sources effectively, people must have sufficient knowledge and basic financial background. As for families, financial management practices become more important since they have to allocate sources of income into many obligations.

Households in the Surveys of Consumers reported on eighteen financialmanagement behaviors, ranging from very basic money management skills (tracking expenses, paying bills on time) to more sophisticated ones (diversifying investments) (Hilgert et al., 2002). This study shown a fairly large percentage of individuals reportedwhat are considered "good" cash-flow management practices: $89 \%$ of households had a checking account, $88 \%$ paid all their bills on time, and $75 \%$ reconciled their checkbook every month. As to saving practices, the data show that while $80 \%$ and $63 \%$ had a savings account and an emergency fund, respectively, only $39 \%$ were saving for long-term goals, such as for education, a car, or a home (Hilgert et al., 2002). In fact inadequate savings not only negatively affects financial management (Delafrooz\&Paim, 2011a). On the other hand, higher educated individuals, higher financial knowledge does not necessarily translate into better financial management unless the values of living within one means is cultivated along financial knowledge (Ali, 2013).

\section{ii. Financial Literacy}

Financial literacy can be defined as the ways how people manage their money in termsof insuring, investing, saving and budgeting (Mahdzan\&Tabiani, 2013). Financial literacy also defined as the ability to use knowledge and skills to manage financial resources effectively for a life time of financial well-being (Suwanaphan, 2013). It also refers to a skill that can help people to make financial decisions effectively. Therefore, individuals who are financially literate are expected to possess basic understanding of the financial concepts such as interest rate, inflation rate, compound interest, and risk (Sabri\&Juen, 2014).

Financial literacy was found to play an important role in explaining attitudes toward saving. In addition, recognizing that individuals possess low financial literacy and do not plan for retirement brings inevitably to the issue of mistakes (Delafrooz\&Paim, 2011a). Further extend, study found that financial literacy increases the likelihood of planning for retirement and that people who plan for retirement have higher levels of wealth compared to people who do not plan(Khan \&Abdullah, 2010). 


\section{iii. Financial Distress}

Financial distress can be defined as a reaction, such as mental or physical discomfort, to stress about one's state of general financial well-being. In particular, it includes perceptions about one's capacity to manage economic resources (such as income and savings), pay bills, repay debts, and provide for the needs and wants of life (Hamid\& Abdullah, 2009). Financial distress at an individual level can actually have serious consequences on future financial position. There is a relationship between financial management and financial distress. Apparently, the economic hardship may be acute or chronic, anticipated or unanticipated, and it may be attributable to uncontrollable forces (such as the regional economy) or controllable forces (e.g., poor financial management) (Davis \&Mantler, 2004). McCarthy (2011) found that timepreferences, financial management and attitudes towards debt tend to be important predictors of a household's financial distress level, after controlling for demographics and income. Financial distress may affect individual life in many aspects, ranging from savings attitude, emotional, productivity level at workplace, retirement plan and family.

Based on thestudy of a representative sample of 810 adults from Utah, reported that a greater degree of financial stress predicted not only lower ratings of life satisfaction, but it also predicted lower ratings of satisfaction with one's marriage and lower ratings of satisfaction with one's role as parent (Davies et al., 2004). Certainly people with a larger pool of savings from which they may draw in times of financial stress will feel less financial pressure (or it maytake them longer to feel the pressure), but once the pressure is there, they are as apt to experience the consequences of financial stress as those who no longer have a pool of savings from which to draw (Davies et al., 2004).

\section{Data andMethodology}

\section{i. Questionnaires}

This paper utilized questionnaire- based surveys to obtain information about saving behavior and financial constraints. The questionnaire consists of 5 parts. Part A, demography survey to find out the background of the respondents. While Part $B$ tends to seek out information on respondent's financial management. Part $\mathrm{C}$ tries to examine the financial literacy of the respondent and Part D to evaluate the level of financial distress among respondent. The final part is openended questions related to their opinion on how to improve individual saving attitude. They were asked to circle the answers using five-point Likert scale ranging from $1=$ strongly disagree to $5=$ strongly agree.Before the actual data collection was conducted, a pretest was done involving 30 respondents to check for the reliability of the questionnaires.

\section{ii. Participants}

The respondents of this study comprise of all academic staff and administrativeofInternational Islamic University College Selangor (KUIS).The questionnaire was distributed to a total of 150 employees. A total of 103 employees returned accomplished the survey questions made up an overall response rate of $69 \%$.

\section{iii. Measurement Instrument}

The collected data was coded and analyzed using SPSS 20 (Statistical Package for the Social Science). Descriptive statistics such as frequency, percentage, and mean were used to interpret the data.

\section{Result and Discussion}

The results are presented in Table 1 and Table 2 below. Table 1 shows the summary of reliability statistics, whereas Table 2 displays the summary of Pearson 
correlation analysis. Of the 103 staff analyzed in the survey, $24 \%$ were male and $76 \%$ were female. Majority of the respondents were 35-44 years old (48\%) and 25-34 years old (41\%). We find about $49 \%$ and $24 \%$ of the respondents having postgraduate and bachelor degree qualifications, respectively. Overall, most of the respondents fall within the incomes of RM4001-RM5000 (27\%) and below RM2000 (26\%).

Table 1: Summary of Reliability Statistics

\begin{tabular}{|l|c|c|}
\hline \multicolumn{1}{|c|}{ Construct } & $\begin{array}{c}\text { Cronbach's } \\
\text { Alpha }\end{array}$ & $\begin{array}{c}\text { Number of } \\
\text { Items }\end{array}$ \\
\hline Financial & 0.716 & 5 \\
Management & 0.612 & 7 \\
(IV1) & 0.796 & 5 \\
Financial & 0.749 & 5 \\
Literacy (IV2) & & \\
Financial & & \\
Distress (IV3) & & \\
Saving Behavior & & \\
(DV) & & \\
\hline
\end{tabular}

The research instrument was tested for reliability using the Cronbach's coefficient as reported in Table 1. The Cronbach's alpha for all dimensions are exceeding the minimum alpha value of 0.6 (Hair et al., 1998), thus the construct measures deemed reliable and all items in the construct measures are retained.

Table 2: Summary of Pearson Correlation Analysis

\begin{tabular}{|l|c|}
\hline & $\begin{array}{c}\text { Saving Behavior } \\
\text { (DV) }\end{array}$ \\
\hline $\begin{array}{l}\text { Financial Management } \\
\text { (IV1) }\end{array}$ & $0.816^{* *}$ \\
Pearson Correlation & .000 \\
Sig. (2-tailed) & \\
Financial Literacy (IV2) & $0.473^{* *}$ \\
Pearson Correlation & .000 \\
Sig. (2-tailed) & \\
Financial Distress (IV3) & $0.600^{* *}$ \\
Pearson Correlation & .000 \\
Sig. (2-tailed) & \\
Saving Behavior (DV) & 1 \\
Pearson Correlation & \\
Sig. (2-tailed) & \\
\hline
\end{tabular}

Note: **. Correlation is significant at the 0.01 level (2-tailed).

According to Table 2, all the independent variables have positive association with the dependent variables. FM has the strongest relationship with SB $(r=0.816)$, followed by the FD $(r=0.600)$ and FL $(r=$ 0.473). All hypotheses of this study are accepted as the p-values are less than 0.05 (Malhotra, 2010). It indicates that all these 3 independent variables significantly predicted saving behavior. Furthermore, financial management practice is the major determinants of saving behavior due to the strongest relationship with saving behavior.

From an open ended question of the survey, we found that there are 7 categories of opinion suggested by the respondents to improve an individual saving attitude. Out of 103 total respondents, $52(50.5 \%)$ responded to the question. Majority of them (51.9\%) promotes consistent savings, 12 respondents $(23.1 \%)$ proposed to spend based on necessity, 4 respondents $(7.7 \%)$ suggested planning before you spending and 1 respondent $(1.9 \%)$ urged to take Takaful policy. It is quite interesting to find that 6 respondents $(11.5 \%)$ of total respondents said, to improve savings attitudes one has to gain knowledge while one respondent $(1.9 \%)$ proposed give more to gain more and another $1.9 \%$ suggested to do side business to gain income for savings. Overall, the finding of study shows that more than half of the respondents aware that financial distress can be managed by financial literacy provided that you have the financial knowledge.

\section{Conclusion and Recommendation}

This study has two primary objectives, which are (1) To examine the major determinants of saving among KUIS staff and (2) To describe the relationship 
between financial constraints, financial management, financial literacy and financial distress. The study can be concluded that all the independent variables (FM, FL and FD) have positive relationship with the saving behavior. Majority of the respondents agree that financial knowledge is very important in managing their saving behavior. Thus, several initiatives can be done in order to help people to improve their saving behavior and getting free from the financial distress. First, KUIS should introduce workplace-based financial education programs. According to Shepellfgi Research Group (2009), these programs have proven to be quite effective in helping employees make better financial decisions and reduce their financial related stress. Secondly, KUIS should consistently educating staff about the importance of improving saving behavior. This supported by McKean et al.(2005) that education system is also a good alternative to promote a more-saving minded population. Thus, it is hoping that the financial management knowledge can guide the staff to rebalance their saving behavior pattern for current and retirement purpose. Ali (2013) explained the need for financial literacy initiatives to ensure effective financial planning for retirement and ability to sustain through retirement.

\section{References}

Ali, S. (2013). Financial literacy in Malaysia: issues and status update. In International Seminar on Financial Education and Retirement Savings. Central Bank of Malaysia.

Davis, C. G. \&Mantler, J. (2004). The consequences of financial stress for individuals, families, and society. Centre for Research on Stress, Coping and Well-being Carleton University, Ottawa.

Delafrooz, N. \&Paim, L. (2011a). Personal saving behavior among Malaysian employees: socio demographic comparison. In International Conference on Social Science and Humanity, 5, 361-363.

Delafrooz, N. \&Paim, L. (2011b). Determinants of saving behavior and financial problem among employees in Malaysia. Australian Journal of Basic and Applied Sciences, 5(7), 222-228.

Hair, J. F., Anderson, R. E., Tatham, R. L., \& Blank, W. C. (1998). Multivariate data analysis, $5^{\text {th }}$ Ed., Prentice-Hall, Englewood Cliffs, NJ.

Hamid, N. H. A. \& Abdullah, A. (2009). Financial distress among employees: an exploratory study. In Prosiding Perkem IV, 2, 395-405.

Hilgert, M. A., Hogarth, J. M., Vitt, L. A., \& Anderson, C. (2002). Household financial management: the connection between knowledge and behavior.Federal Reserve Bulletin, 106.

Khan, H. H. A. \& Abdullah, H., (2010). Saving determinants in Malaysia. JurnalEkonomi Malaysia, 44, 23-34.

Krah, R. Y., Aveh, F. K., \& Addo, R. (2014). An exploratory study of financial management practices among Ghanaian households. International Journal of Management and Sustainability, 3(7), 393-414.

Mahdzan, N. S., \& Tabiani, S. (2013). The impact of financial literacy on individual saving: an exploratory study in the Malaysian context. Transformations in Business \& Economics, 12(1), 41-55.

Malhotra, N. K. (2010). Marketing research: an applied orientation, $6^{\text {th }}$ Ed., Pearson Education, Inc. USA.

McCarthy, Y. (2011). Behavioral characteristics and financial distress. Working Paper Series, 1303, European Central Bank.

McKean, L., Lessem, S., Bax, E. \& Hernandez, N. (2005). Money management by low-income 
households: earning, spending, saving, and accessing financial services. Center for Impact Research.

Rajni, D. (2010). Saving and investment behaviour in select East Asian countries (Korea, Malaysia, Thailand, and Indonesia). Journal of Management and Information Technology, 2(1), 1-15.

Sabri, M. F., \& Juen, T. T. (2014). The influence of financial literacy, saving behaviour, and financial management on retirement confidence among women working in the Malaysian public sector. Asian Social Science, 10(14), 40-51.

Shepellfgi Research Group (2009). Financial distress impacts health and productivity: employees turning to EAP for help, 5(1).

Suwanaphan, S. (2013). Personal financial literacy of academic support employee in Chiang Mai University. InManagement, Knowledge amd Learning International Conference, 1061-1065. 